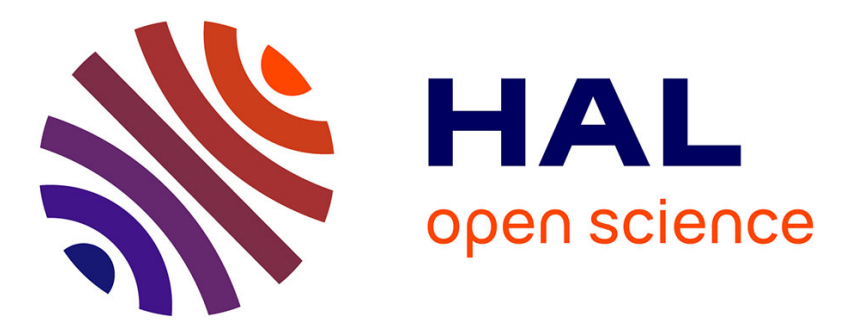

\title{
Dynamic of screw superlattice dislocations in a $\gamma 112$ structure. In situ observation at high temperature
}

\author{
N. Clement, Daniel Caillard, A. Beneteau, A. Coujou
}

\section{To cite this version:}

N. Clement, Daniel Caillard, A. Beneteau, A. Coujou. Dynamic of screw superlattice dislocations in a $\gamma 112$ structure. In situ observation at high temperature. Revue de Physique Appliquée, 1988, 23

(4), pp.675-675. 10.1051/rphysap:01988002304067500 . jpa-00245824

\section{HAL Id: jpa-00245824 https://hal.science/jpa-00245824}

Submitted on 1 Jan 1988

HAL is a multi-disciplinary open access archive for the deposit and dissemination of scientific research documents, whether they are published or not. The documents may come from teaching and research institutions in France or abroad, or from public or private research centers.
L'archive ouverte pluridisciplinaire HAL, est destinée au dépôt et à la diffusion de documents scientifiques de niveau recherche, publiés ou non, émanant des établissements d'enseignement et de recherche français ou étrangers, des laboratoires publics ou privés. 
DYNAMIC OF SCREW SUPERLATTICE DISLOCATIONS IN A $\gamma^{\prime} \mathrm{L}_{2}{ }_{2}$ STRUCTURE. IN SITU OBSERVATION AT HIGH TEMPERATURE N.CLEMENT, D.CAILlaRD, A.BENETEAU, A.COUJOU ${ }^{\star}$

Groupe de deformation plastique - Laboratoire d'Optique Electronique du CNRS.

B.P.4317,31062 Toulouse Cedex. France

Universite Paul Sabatier, 31062 Toulouse. France

Nickel base intermetallic compounds, with $\mathrm{L} 12$ structure(here the $\gamma^{\prime}$ phase of $\mathrm{CMSX}_{2}$ monocrystalline superalloy) commonly exhibit an anomalous stress vs temperature dependence : the flow stress increases remarkably with increasing temperature, reaching a peak value at a temperature which depends on composition and orientation (around $760^{\circ} \mathrm{C}$ for $\mathrm{CMSX}_{2}$ ).

Two different modes of thermally activated mechanisms have been proposed :

- the first one, related to the cross slip of screw segments from $\{111\}$ primary slip plane where they are mobile, to the $\{010\}$ cross slip plane where they are assumed to be sessile. This core dissociation can occur all along the dislocation which creates the so-called sessile "KearWildorf" locks (1). It may also occur by local pinning points, due to cross slipped $\langle 010\rangle$ segments, the production of which increases with temperature (This corresponds to Takeuchi and Kuramoto (2) or Paidar, Pope and Vitek (3) models).

- the other one at intermediate and high temperatures, related to the climb of edge dislocations by a diffusion process (Flinn model(4)).

In order to determine the detailed deformation processes, we have performed in situ experiments between 25 and $750^{\circ} \mathrm{C}$, and the dislocation movements were recorded and analysed. Because of the high temperatures and stresses involved (1000 $\mathrm{MPa}$ at $750^{\circ} \mathrm{C}$ ), microsamples cannot be glued, and their design is particularly important. Fig.l shows the microsample shape which provides a stress concentration around the thin edged hole, in the hatched area with expected Schmid factor.

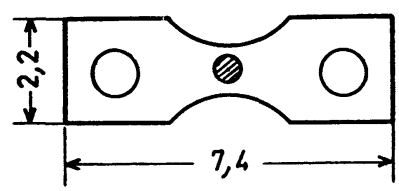

Fig. 1

These microsamples were cut out of a single crystal grown at ONERA (5). The choosen orientation has a [110] tensile axis; under such conditions, two octaedric planes (iil) and (iIi) (Schmid factor $\simeq 0.4$ ) and two cubic planes (001) and (010) (Schmid factor $\simeq 0.35$ ) are activated.

In these experiments different types of behaviour are observed:

At $400^{\circ} \mathrm{C}$-We observe a source with one anchoring point, belonging to the (010)[101] glide system. The emitted dislocations have a jerky movement, and they are the most frequently parallel to two particular directions, as described below in Fig. 2, where the frequence of these directions is reported.

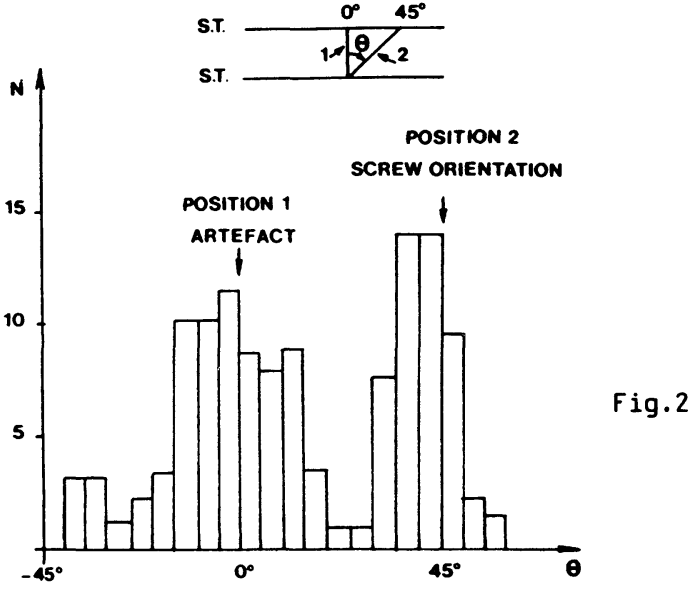

Measurements are performed each second. Position 1 is just perpendicular to the slip traces (S.T.) and corresponds to a minimum length of the dislocation in the thin foil : this is obviously an artefact. Position 2 corresponds exactly to the screw orientation and appear to be a real stable dynamic position.

At $600^{\circ} \mathrm{C}$ - When the stress is applied, the dislocaEion density strongly increases, and rectilinear dislocations have a jerky movement in the cubic planes, either isolated or in pile-ups. Under these stresses, they may be curved on strong obstacles and take then a bowed configuration constituted by two crystallographic directions : the screw one, and the other near [103] or [102]. This special configuration corresponds to a very strong locking and may be consistent with climb dissociation (6). Unlocking of such configuration is also observed.

At $750^{\circ} \mathrm{C} \simeq \mathrm{T}$ peak - The observed moving screws are readily rectilinear. Therefore it seems that the corresponding strong friction force is temperature dependent and maximum at the peak temperature. The local stress in (010) may be evaluated from dislocation radii of curvature; its variation with temperature is consistent with macroscopic measurements.

These different aspects are analysed in terms of the preceding theoretical models.

References :

(1) KEAR B.H. and WILSDORF H.G.F., Trans. TSM AIME, 224,382 (1962)

(2) TAKEUCHI S. and KURAMOTO E., J. Phys. Soc. Japan, 31, 1282 (1971)

(3) PAIDAR V., POPE D.P. and VITEK V., Acta Met., $32,435(1984)$

(4) FLINN P.A., Trans. TSM AIME, 218, 145 (1960)

(5) CARON P. and KHAN T., Mat. Sci. Eng., 61, 173 (1983)

(6) VEYSSIERE P., Phil. Mag., 50, 189 (1984)

We are thankful to the Direction des Recherches, Etudes et Techniques of the French Defense Minister for the financial help they have brought to us. 